\title{
Keabadian Air:Telaah Teologi Energi dalam Islam dan Hukum Termodinamika
}

\section{I] A SUNTANA}

ijasuntana@uinsgd.ac.id

(Fakultas Syariah dan Hukum Universitas Islam Negeri Sunan Gunung Djati Bandung)

\section{ABSTRACT}

This paper aims to compare concepts of energy theology in I slam with Thermodynamic theory, especially concerning water immortality. The research question discussed in this paper is whether the views of Islamic theology, represented by the M u'tazilite and A sharite schools regarding natural substances havea correlation with energy theology among ecologists, especially with the laws of Thermodynamics? The results of the study found that the M u'tazilite theological school saw that water energy has an eternal character, so it would not run out if people exploit it. This view is in line with the law of Thermodynamics I, which confirms that energy has the character of immortality. M eanwhile, A sharite states that natural substances do not have a character of eternality, including water energy. The theological views of A sharite are in line with the law of Thermodynamics II, which states that energy experiences a shrinkage. The analysis of this different stances on energy theology can be used as a concept for environmental exploitation or preservation. A ccording to the M u'tazilite view, the exploitation of the environment can be carried out indefinitely, because the substance of nature has no limit (eternal). M eanwhile, based on A sharite view, the exploitation of nature must must be limited, because natural substances have limited time and volume, which need to be preserved.

K eyword: Thermodynamic, M u'tazilite, A sharite

\section{ABSTRAK:}

Artikel ini membahas tentang perbandingan konsep teologi energi dalam Islam dengan teori termodinamika, terutama menyan gkut tentang keabadian air. Pertanyaan riset yang dibahas dalam artikel ini adal ah apakah pandangan teologi Islam, yang diwakili oleh aliran Mu'tazilah dan Al-As'ariyah perihal substansi alam memiliki korelasi dengan teologi energi di kalangan para ekolog, terutama dengan hukum Termodinamika? H asil pembacaan penulis ditemukan bahwa aliran kalam M u'tazilah memandang bahwa energi air memiliki karakter kekal, 
sehingga tidak akan habis dieksploitasi oleh manusia. Pandangan ini senada dengan hukum Termodinamika I, yang menegaskan bahwa energi memiliki karakter keabadian. Sedangkan, aliran AI-As'yariyah menyatakan bahwa substansi alam tidak memiliki karakter abadi, termasuk energi air. Pandangan teologi AlA'asyariyah sehaluan dan satu prinsip dengan hukum Termodinamika II, yang menyatakan bahwa energi mengalami penyusutan. Telaah atas pendirian yang berbeda dalam teologi energi ini dapat dijadikan sebagai konsep eksploitasi atau pelestarian lingkungan. Berdasarkan teori Mu'tazilah, eksploitasi lingkungan dapat dilakukan tanpa batas, karena substansi alam tidak memiliki batas (abadi). A dapun didasarkan pada pandangan Al-A s'ariyah, eksploitasi alam harus memertimbangkan sisi keterbatasannya, karena substansi alam berbatas waktu dan volume, yang nota bene perlu untuk dijaga kelestariannya.

Kata kunci: termodinamika, M u'tazilah, A I-A sya'ariyah.

\section{PENDAHULUAN}

Para peneliti lingkungan meyakini bahwa agama memainkan peran penting dalam persepsi publik mengenai rekayasa lingkungan serta menangani perubahan iklim. Konsep-konsep agama dapat berkontribusi penting bagi wacana rekaysa lingkungan (geoengineering), sebagaimana konsepkonsep yang datang dari kalangan saintis, insinyur, dan pembuat kebijakan. ${ }^{1}$

Forrest Clingerman dan Kevin O'Brien menyebutkan, pelibatan agama dalam diskursus lingkungan terkait dengan empat alasan, yaitu (1) agama sangat berpengaruh terhadap kebanyakan cara pandang masyarakat dalam memahami diri mereka dan lingkungannya, (2) agama dapat menguatkan otoritas ilmiah, (3) Narasi dan simbol religius bisa memberi bingkai untuk memahami perihal rekayasa lingkungan (geoengineering), dan (4) agama menawarkan sejumlah kosakata dan retorika moral. Para sarjana teologi, etikawan, dan para pengkaji agama dapat bertindak sebagai mediator antara komunitas sains dan religi, memberikan suara kritis dalam memahami dan menyikapi lingkungan, dan dalam melibatkan masyarakat luas. ${ }^{2}$

Dalam kajian sains Islam, teologi lingkungan merupakan kajian teologi tematik yang berkorelasi dengan pembahasan teologi Islam (kalam) secara umum. JB. Banawiratma Sj., J. M uller Sj, ${ }^{3}$ dan M ujiyono Abdillah ${ }^{4}$ merupakan di antara para peneliti yang memiliki perhatian khusus pada masalah teologi lingkungan, dengan perspektif keagamaan.

Seyyed Hosseen Nasr memopularkan telaah teologi lingkungan dengan a religious nature, dengan inti dasar konsep bahwa fungsi utama manusia dicipta Tuhan di alam ini adalah sebagai penjaga lingkungan (alam). 
${ }^{5}$ Adapun Al-Damkhi memopularkan telaahnya atas teologi lingkungan dalam Islam dengan istilah environmental ethics. Penelitian Al-Damkhi menyoroti kerusakan lingkungan di Kuwait dan penghancuran rawa-rawa di Irak bagian selatan, yang disebut olehnya dengan istilah "manipulasi agresif sumberdaya alam." Ditengarai oleh Al-Damkhi bahwa telah terjadi pengabaian dan pelanggaran terhadap prinsip-prinsip lingkungan dalam Islam. ${ }^{6}$

Kajian teologi lingkungan dalam Islam belakangan ini muncul sebagai penyikapan positif akademisi teologi M uslim mutakhir terhadap persoalan lingkungan. ${ }^{7}$ Para teolog M uslim klasik tidak mengembangkan kajian teologi lingkungan secara eksplisit. Walaupun demikian, secara implisit kajian tentang teologi lingkungan sudah tersirat dalam pandangan-pandangan kalam para teolog muslim masa lalu dari berbagai sekte, terutama dalam pembahasan dan perdebatan mereka mengenai qadîm ${ }^{8}$ atau hâdits ${ }^{9}$ tentang jagat raya.

Salah satu energi yang tersedia di alam ini dan bagian dari fakta lingkungan adalah air. Belakangan ini air mendapatkan perhatian dari para peneliti, yang dihubungkan dengan teologi. Terry Maksymowych salah satu di antara sekian peneliti yang memiliki perhatian fokus pada hubungan air dengan teologi. ${ }^{10}$

Secara eksplisit, para ulama M uslim masa lalu tidak menaruh perhatian khusus terhadap air dari sudut pandang teologis. Telaah air oleh mereka lebih banyak terarah pada kedudukan air sebagai benda ritual yang memiliki kekuatan spiritual untuk menghasilkan kesucian kepada makhluk. Padahal, Al-Quran menyebutkan air sebagai benda yang istimewa, karena dijadikan sebagai media terbentuknya kehidupan di jagat raya. ${ }^{11}$ Secara umum, pembahasan tentang air dalam buku-buku yang ditulis oleh para ulama Islam klasik lebih diarahkan pada hukum pengelolaannya, bukan pada substansi dan karakter air sebagai benda tercipta (makhluk). Materi dan konsep pengelolaan air yang dikembangkan merupakan interpretasi teks syariat, praktik sejarah, dan pemikiran mazhab hukum yang dianut.

Berdasarkan corak kajian, penulisan konsep air dalam ranah pengeIolaan terbagi kepada tiga, yaitu (1) Panduan. Tulisan bercorak ini seperti dilakukan oleh Al-Mawardi dalam buku Hukum-Hukum Pemerintahan (AlAhkam Al-Sulthaniyyah). Buku ini ditulis oleh Al-M awardi dengan kapasitas sebagai penasihat khalifah Saljuk awal, Al-Qaim, di Baghdad. Pemerintahan Al-Qaim meminta kepada Al-M awardi untuk merumuskan aturan-aturan 
sebagai rujukan dirinya dalam membuat kebijakan negara, salah satunya dalam bidang pengelolaan air, (2) Wacana hukum. Penulisan corak ini lebih cenderung sebagai kajian hukum air dalam ranah wacana akademik, seperti dilakukan oleh M uhammad Syarbini Khatib dalam Al-Iqna fi Hall Alfazh Abi Syuja dengan fokus analisis pada mazhab Syafi'i dan Abu Ya'la dalam Al-Ahkam Al-Sulthaniyyah dengan fokus analisis pada mazhab Hanbali, (3) Fatwa. Penulisan corak ini berupa opini-opini hukum yang disampaikan kepada pihak yang mengajukan pertanyaan, seperti dilakukan oleh Abu Yusuf dalam buku Al-Kharaj. Dalam buku tersebut Abu Yusuf menjelaskan perihal hukum pengairan sebagai jawaban atas pertanyaan yang diajukan oleh Khalifah Harun Al-Rasyid kepadanya. Sebagai benda yang krusial dan memiliki dimensi ketuhanan (karena dijadikan media oleh Tuhan sebagai asal mula kehidupan), mesti memiliki informasi ilmiah yang menyangkut ketuhanan (ontologi teologis) kealaman. Oleh sebab itu, sangat beralasan apabila air mendapat telaah dalam ranah teologis.

Berdasarkan asumsi sementara, terdapat pertalian konsep dan premis antara konsep teologi dalam Islam, terutama dengan dua aliran kalammeanstream, yaitu Mu'tazilah dan Asy'ariyyah, dengan teori termodinamika, yaitu sebuah pandangan ilmiah mengenai kekekalan energi. Teori termodinamika mengalami kenaikan derajat, ketika teori ini berubah menjadi hukum, karena sangat kuat dan tidak terbantahkan. Sampai saat ini belum ditemukan teori yang lebih kuat tentang kekekalan energi dibanding dengan teori termodinamika, sehingga di kalangan para ahli lingkungan teori ini berubah dari sekadar teori menjadi hukum.

Persinggungan konsep teologi dalam Islam, yang diwakili oleh Mu'tazilah dan Al-Asy'ariyah, dengan hukum termodinamika terdapat dalam hal memahami keabadian dan ketidakabadian alam, salah satunya tentang energi air. Apakah substansi alam ini kekal (a'badi) atau berbatas waktu (mua'jjal)? Dua kutub pemikiran teologi tersebut perlu mendapat telaah untuk ditakar kekuatannya, sehingga dapat ditarik sebagai basis teologi dalam melakukan pengelolaan sumber daya air.

\section{SUBSTANSI FISIK DAN KIMIAWI AIR}

Unsur fisik dan kimiawi air adalah gabungan dua atom hidrogen dengan satu atom oksigen, yang disimbolkan dengan rumus kimia $\mathrm{H}_{2} \mathrm{O} .{ }^{12}$ Gabungan dua atom tersebut merupakan cairan yang menjadi penopang utama kehidupan di muka bumi. Dalam keadaan bening, air tidak memiliki 


\section{$246 \mid$ нeroum}

warna, rasa, dan bau. ${ }^{13}$

Di kalangan para ulama Islam terjadi perbedaan pendapat dalam hal apakah air itu berawarna atau tidak. Mayoritas ulama Islam menyatakan bahwa air memiliki warna, sebagaimana tertuang dalam sabda Nabi Muhammad yang menyatakan, Air itu suci. Tidak ada sesuatu pun yang menjadikannya najis kecuali (karena tercampuri) benda yang mengubah warnanya. Hadis ini, (terutama dalam kata, mengubah warnanya), menurut sebagian ulama Islam merupakan dalil bahwa air itu memiliki warna, karena Nabi Muhammad menyebutkan bahwa air itu berwarna. Selain itu, air adalah benda fisik yang dapat terlihat oleh mata. Sebagai benda yang terlihat oleh mata dipastikan bahwa air adalah benda berwarna, dikarenakan mata hanya bisa memandang benda-benda yang memiliki warna. Sementara itu, sebagian ulama yang menyatakan bahwa air tidak memiliki warna berasumsi bahwa air adalah benda yang pertama kali tersedia dia alam dan yang memberi warna kepada benda-benda lainnya. ${ }^{14}$

Perdebatan perihal kewarnaan air mengimbas kepada sebutan bentuk warna air. Di antara ahli hukum Islam menyebutkan bahwa warna air adalah putih (al-bayadh). Pandangan ini didasarkan secara normatif kepada sebuah pernyataan Nabi M uhammad yang menyebutkan bahwa air lebih putih dari warna susu. Sebagian ahli hukum Islam menyebutkan bahwa warna air tergantung kepada warna wadah atau tempat di mana ia berada. Apabila wadah air berwarna merah, air pun mengikuti warna tersebut. Bila wadahnya berwarna hijau, air pun mengikuti warna tersebut. Hal ini terkait dengan kebradaan air yang tembus pandang, sehingga tetap bisa menampakkan warna tempatnya. ${ }^{15}$

Sifat air digolongkan ke dalam tiga bagian, yaitu sifat fisis, kimiawi, dan biologis. Secara fisis, wujud air di bumi berbentuk padat sebagai es, berbentuk cair sebagai air, dan berbentuk gas sebagai uap air. Bentuk fisis ini tergantung keadaan cuaca yang ada di tempat air itu berada. Kepadatan (density) air, seperti wujudnya, tergantung dari temperatur dan tekanan barometris. ${ }^{16}$ Pada umumnya, densitas meningkat dengan menurunnya temperatur, sampai tercapai maksimum pada $4^{\circ}$ Celcius. Apabila temperatur turun lagi, maka densitas akan turun pula.Secara kimiawi, air bersih mempunyai $\mathrm{pH}=7$, dan oxigen terlarut $(=\mathrm{DO})$ jenuh pada $9 \mathrm{mg} / \mathrm{l}^{17}$

Air merupakan pelarut universal, hampir semua jenis zat dapat larut di alam air. Air juga merupakan cairan biologis, yakni didapat di dalam tubuh semua organisme. Dengan demikian, spesies kimiawi yang terkandung di 
dalam air berjumlah sangat besar. ${ }^{18} \mathrm{Hal}$ ini memiliki korelasi dengan pernyataan Al-Quran yang menyatakan bahwa Allah menjadikan segala makhluk hidup dari air. ${ }^{19}$ Beberapa data menunjukkan bahwa unsur cairan dalam tubuh setiap makhluk hidup selalu mencapai $80 \%$ dari total isi yang terkandung.

Secara biologis di dalam air selalu terdapat kehidupan, baik fauna maupun flora. Benda-benda yang hidup dalam air berpengaruh timbal balik terhadap kualitas air. Di dalam suatu lingkungan air, terdapat berbagai benda hidup yang khas bagi lingkungan tersebut. Benda hidup di perairan dibagi ke dalam organisme yang native dan yang tidak native bagi organisme dan tidak patogen terhadap manusia. Organisme yang tidak native bisa berasal dari air limbah, air hujan, debu, dan pengotoran lainnya. Organisme ini dapat hidup di dalam air yang mengandung zat hara/ makanan baginya. Sebagaimana halnya semua organisme, setiap organisme di dalam perairan mempunyai fungsi yang sangat khusus dalam lingkungan tersebut dan membentuk ekosistem aquatik yang khas pula. ${ }^{20}$

Al-M ishri, ${ }^{21}$ ahli pengairan Islam kontemporer dari Kairo, membagi air kepada beberapa jenis. Pertama, air tawar, yaitu air yang tak mengandung banyak garam di dalamnya, sehingga terasa menyegarkan bila diminum. Kedua, air asin adalah air yang mengandung banyak garam di dalamnya (bila dibandingkan dengan kandungan garam yang terdapat dalam air tawar, air tersebut memiliki kadar garam lebih). Ketiga, air mineral, yaitu air alami yang keluar dari perut bumi yang mengandung garam dalam kadar tertentu sehingga menimbulkan rasa khusus, yang terkadang memiliki khasiat medis. Keempat, air hujan (air angkasa), yaitu air yang turun dari langit dan tidak mengandung garam, ${ }^{22}$ namun memiliki unsurunsur tertentu, seperti $\mathrm{HF}, \mathrm{CL}$, dan $\mathrm{NO}_{3}$.

Air adalah substansi kimiawi dengan rumus kimia $\mathrm{H}_{2} \mathrm{O}$ : satu molekul air tersusun atas dua atom hidrogen yang terikat secara kovalen pada satu atom oksigen. Air bersifat tidak berwarna, tidak berasa dan tidak berbau pada kondisi standar, yaitu pada tekanan $100 \mathrm{kPa}$ (1 bar) dan temperatur $273,15 \mathrm{~K}\left(0^{\circ} \mathrm{C}\right)$. Zat kimia ini merupakan suatu pelarut yang penting, yang memiliki kemampuan untuk melarutkan banyak zat kimia lainnya, seperti garam, gula, asam, beberapa jenis gas, dan banyak macam molekul organik. ${ }^{23}$

Air sering disebut sebagai pelarut universal karena air melarutkan banyak zat kimia. Air berada dalam keseimbangan dinamis antara fase 
cair dan padat di bawah tekanan dan temperatur standar. Dalam bentuk ion, air dapat dideskripsikan sebagai sebuah ion hidrogen $(\mathrm{H}+)$ yang berasosiasi (berikatan) dengan sebuah ion hidroksida (OH-). ${ }^{24}$

Molekul air dapat diuraikan menjadi unsur-unsur asalnya dengan mengalirinya arus listrik. Proses ini disebut elektrolisis air. Pada katoda, dua molekul air bereaksi dengan menangkap dua elektron, tereduksi menjadi gas $\mathrm{H}_{2}$ dan ion hidrokida ( $\mathrm{OH}-$ ). Sementara itu, pada anoda, dua molekul air lain terurai menjadi gas oksigen $\left(\mathrm{O}_{2}\right)$, melepaskan 4 ion $\mathrm{H}+$ serta mengalirkan elektron ke katoda. Ion $\mathrm{H}+$ dan $\mathrm{OH}$ - mengalami netralisasi sehingga terbentuk kembali beberapa molekul air. ${ }^{25}$

Air adalah pelarut yang kuat, melarutkan banyak jenis zat kimia. Zatzat yang bercampur dan larut dengan baik dalam air (misalnya garamgaram) disebut sebagai zat-zat "hidrofilik" (pencinta air). Zat-zat yang tidak mudah tercampur dengan air (misalnya lemak dan minyak) disebut sebagai zat-zat "hidrofobik" (takut air). Kelarutan suatu zat dalam air ditentukan oleh dapat tidaknya zat tersebut menandingi kekuatan gaya tarik-menarik listrik (gaya intermolekul dipol-dipol) antara molekul-molekul air. Jika suatu zat tidak mampu menandingi gaya tarik-menarik antar molekul air, molekul-molekul zat tersebut tidak larut dan akan mengendap dalam air. ${ }^{26}$

Air memiliki tegangan permukaan yang besar yang disebabkan oleh kuatnya sifat kohesi antar molekul-molekul air. Hal ini dapat diamati saat sejumlah kecil air ditempatkan dalam sebuah permukaan yang tak dapat terbasahi atau terlarutkan (non-soluble); air tersebut akan berkumpul sebagai sebuah tetesan. Di atas sebuah permukaan gelas yang amat bersih atau bepermukaan amat halus air dapat membentuk suatu lapisan tipis (thin film) karena gaya tarik molekular antara gelas dan molekul air (gaya adhesi) lebih kuat ketimbang gaya kohesi antar molekul air. ${ }^{27}$ Menurut para ulama Islam, sebagai benda istimewa air memiliki sifat rumit dan istimewa terkait dengan molekul-molekulnya. Sifat-sifat istimewa tersebut tidak dimiliki oleh benda lain di muka bumi, sehingga air bukan benda yang tercipta melalui proses kimiawi pada permukaan bumi melainkan terproses di tempat lain. Terkait dengan itu, AI-Quran menggunakan kata انزل (anzala) untuk menyebut proses turun air ke muka bumi. Sebagian ahli tafsir menyebutkan bahwa kata نزل mengandung arti pemindahan benda dari tempat tertentu ke tempat lain yang bahannya tidak tersedia di tempat tujuan. ${ }^{28}$ 


\section{ASAL MULA AIR DI DUNIA}

Air tidak diam melainkan bersirkulasi yang diakibatkan oleh faktor cahaya. Sirkulasi tersebut membentuk sebuah siklus yang dikenal dengan istilah siklus hidrologis (al-dawrah al-mâiyyah). ${ }^{29}$ Siklus hidrologis menunjukkan bahwa sumber air adalah air itu sendiri, melalui daur hidrologisnya yang bersifat alami. ${ }^{30}$

Air menguap akibat panas matahari. Penguapan ini terjadi pada permukaan air, air yang berada di dalam lapisan tanah bagian atas, air yang ada di dalam tumbuhan, hewan, dan manusia. Uap ini memasuki atmosfir. Di dalam atmosfir uap ini akan menjadi awan, dan dalam kondisi cuaca tertentu dapat mendingin dan berubah bentuk menjadi tetesantetesan air dan jatuh kembali ke permukaan bumi sebagai hujan. ${ }^{31}$

Air hujan yang jatuh ke permukaan bumi ada yang mengalir langsung masuk ke dalam air permukaan (jiryân sathhiy [runoff]), ada yang meresap ke dalam tanah (irtisyâh [percolate]) dan menjadi air tanah (miyâh jawfiyyah), ${ }^{32}$ baik yang dangkal maupun yang dalam, dan ada yang diserap oleh tumbuhan. Air tanah dalam akan timbul ke permukaan sebagai mata air dan menjadi air permukaan. Air permukaan bersama-sama dengan air tanah dangkal, dan air yang berada di dalam tubuh akan menguap kembali untuk menjadi awan. Siklus hidrologis tersebut terus berulang. ${ }^{33}$

Siklus hidrologis termasuk salah satu proses alami air untuk membersihkan dirinya sendiri, dengan syarat kualitas udara dalam keadaan bersih. Apabila udara tercemar, air hujan pun akan tercemar. Abd Al-Fatah AlHusaini, Peneliti dan Konsultan pada Badan Kesehatan Dunia (WHO) Perwakilan Timur Tengah, menyebutkan bahwa air hujan adalah air yang paling bersih dibanding air-air yang keluar dari sumber lain. Namun, kebersihan air tersebut terkait dengan kondisi udara yang dilewati oleh air hujan yang bersangkutan. Apabila udara sudah tercemari, pencemaran tersebut berpengaruh terhadap kualitas air yang melewatinya. ${ }^{34}$

Siklus hidrologis merupakan proses alami air tawar dalam memelihara kelestariannya. Ketika faktor pendukung siklus hidrologis masih tetap terlestarikan, air tawar tidak akan mengalami kekurangan. Akan tetapi, ketika faktor pendukung siklus hidrologis sudah tidak bisa dilestarikan (rusak), seperti telah banyak hutan yang gundul dan tumbuh-tumbuhan yang binasa, akan terjadi kelangkaan air tawar. ${ }^{35}$

Teori tentang siklus hidrologi air tidak menyentuh tentang asal mula air. Siklus ini hanya menjelaskan tentang proses alami air dalam menye- 


\section{$250 \mid$ seroum}

diakan dan melestarikan dirinya, setelah air tersedia di muka bumi. Teori siklus hidrologis bukan penjelasan dari mana asal air datang. Bahkan, ketika muncul pertanyaan, dari mana air yang membentuk lautan di Bumi berasal, tidak terdapat penjelasan yang diterima secara umum oleh semua ilmuwan air. ${ }^{36}$

M uhammad Khamis Al-Zaukah, peneliti lingkungan dari Cairo University, menjelaskan tentang asal muasal air di muka bumi. Dia membagi sumber air menjadi dua:

Pertama, sumber air asal (al-miyah al-fithriyyah) di muka bumi. Air asal adalah air yang pertama kali ada di muka, perut, dan cekungan-cekungan bumi, seperti laut dan samudera. Menurutnya, sumber air asal ada dua, yaitu (1) semburan air dari perut bumi pada masa pertama kali bumi tercipta dan kerak bumi tersusun menjadi keras. Pada masa itu air mulai keluar dari dalam bumi dalam bentuk uap bersama lava yang disemburkan gunung-gunung berapi dari dalam bumi ke permukaan bumi, (2) pendinginan bumi akibat berkurangnya aktivitas vulkanik yang mengakibatkan bumi diselimuti uap air. Uap air tersebut mulai terkondensasi dan turunlah menjadi hujan. Hujan-hujan inilah yang mengisi cekungan-cekungan di Bumi yang kemudian menjadi laut dan menyerap ke dalam perut bumi dan masuk ke dalam aquifer.

Kedua, sumber air di atmosfir. Lapisan atmosfir terbentuk seiring dengan perkembangan yang terjadi di bumi. Jutaan kubik uap yang membumbung dari laut yang terdapat di bumi membentuk sumber air di atmosfir dan turun lagi ke bumi dalam bentuk hujan. ${ }^{37}$

\section{KEKEKALAN AIR: PANDANGAN MU'TAZILAH DAN AL- ASY'ARIYAH}

Berdasarkan ayat 29 Surah Al-Baqarah air adalah benda yang diturunkan dari langit, bukan benda yang muncul secara dengan sendirinya, sebagaimana karakteristik alam secara umum. la sengaja diciptakan oleh Tuhan melalui proses alami, yaitu pelibatan awan dan angin dalam pembentukannya, seperti disebutkan dalam ayat 2 Surah Al-Dzariyyat. Dalam Surah Al-Dzariyah tersebut Allah bersumpah dengan awan (al-hâmilât) yang mengandung hujan sebagai bahan baku air di muka bumi. ${ }^{38}$

Sebagai benda tercipta air merupakan benda alami yang memiliki karakter kealaman secara keseluruhan. Jumlahnya yang terbatas, berubah dari satu keadaan kepada keadaan lain, mengalami kerusakan bentuk, 
dan mengalami kemusnahan adalah sederetan sifat alamiah air. Pandangan ini dipegang oleh para teolog Asya'ariyyah dan oleh sebagian penganut Maturidiyyah, namun ditolak oleh para teolog Mu'tazilah yang menyatakan bahwa alam (termasuk air di dalamnya) memiliki karakter keabadian. M enurut M u'tazilah, dikarenakan unsur air adalah atom dan atom tidak bisa dibagi-bagi lagi dan abadi, maka ia memiliki karakter abadi.

Seyyed Waqar A hmed Hosein, Direktur Institute of Islamic Science, Technology and Development (IISTD), California, ${ }^{39}$ menyebutkan bahwa perdebatan para teolog di seputar alam terkait secara erat dengan perbincangan mengenai energi. Sebagai benda yang diciptakan oleh Allah, menurut kebanyakan teolog Asy'ariyyah, energi adalah terbatas life time (ajal) dan kegunaannya serta akan mengalami kesirnaan. Sedangkan, menurut para teolog Mu'tazilah ( di antaranya adalah Al-Jubai dan AlNizham), energi itu tidak bermula (berasal dari ketiadaan ['adam]) dan tidak terhingga, sehingga bersifat kekal dan lestari (qadim). Energi tidak mengalami sirna tapi sekadar berubah dari satu bentuk ke bentuk lain. ${ }^{40}$

Tidak semua teolog Asy'ariyyah sepakat bahwa alam mengalami kesirnaan. Al-Baqilani, salah seorang ahli teologi Islam dari kalangan Asy'ariyyah, berbeda pandangan dengan kebanyakan koleganya di aliran tersebut. la mengambil teori atom Mu'tazilah dalam menetapkan adanya kekuasaan Tuhan yang tanpa batas. Bagi Al-Baqilani alam ini adalah kumpulan jawhar, yaitu unsur tunggal yang tidak bisa dibagi-bagi lagi. Unsur tunggal tersebut tidak bisa berbentuk wujud kecuali sesudah menerima 'arad, yaitu unsur tersusun yang timbul dari gabungan jawhar dan membentuk dua kutub yang berlawanan. Kutub yang berlawanan tersebut membentuk satu unsur utama yang tidak bisa dibagi-bagi lagi dan disebut dengan jawhar fard. ${ }^{41}$

Teori yang dikemukakan oleh al-Baqillani menguatkan pandangan aliran M u'tazilah yang meyakini keabadian alam secara substansial. Bagi manusia, sebagai bagian dalam alam, esensi tunggal (jawhar fard) adalah substansi ruhani yang akan mengalami keabadian ruhani. Keabadian ruhani inilah yang nanti akan menjadi fenomena di akhirat. Teori yang dikembangkan oleh al-Baqillani, dan juga Mu'tazilah secara keseluruhan, mendukung kuat adanya fenomena ukhrawi (ruhani) yang berkesinambungan dengan fenomena duniawi (materi). Berdasarkan teori Al-Baqillani dan M u'tazilah, substansi yang akan menjadi fenomena ruhani di alam akhirat adalah substansi materi yang pernah menjadi fenomena di alam ini. 


\section{$252 \mid$ serum}

\section{KEKEKALAN ENERGI TEORI TERM ODINAMIKA}

Di kalangan ahli ekologi terdapat perbincangan prinsip energi yang dapat disandingkan dan dibandingkan dengan perbincangan masalah sifat alam di kalangan para ahli teologi Islam. Dapat dikatakan bahwa prinsipprinsip energi yang diyakini dan dibahas oleh para ekolog sebagai formulasi teologi energi di kalangan para ilmuwan lingkungan modern.

Terdapat dua pilar teologi energi di kalangan para ekolog, yaitu hukum termodinamika I dan hukum termodinamika II. Dua hukum termodinamika ini diambil oleh para ekolog sebagai basis pola pandang mereka tentang transformasi energi, perubahan keadaan dan keseimbangan sekumpulan partikel yang membentuk gas, zat cair dan padat terutama yang berhubungan dengan sifat termal atau panas. ${ }^{42}$

Kedua hukum termodinamika tersebut di atas pertama kali dikemukakan oleh Rudolf Julius pada tahun 1850 Masehi. Selanjutnya, hukum termodinamika dikembangkan oleh berbagai pihak dalam berbagai disiplin, sehingga berkembang teori-teori yang merupakan derivasian dari teori termodinamika tersebut. Sebagai contoh adalah teori kinetik James Clerk Maxwell dan teori mekanika statistik Josial Wilard Gibs. Saat ini, termodinamika dikembangkan oleh berbagai masyarakat sains, seperti masyarakat teknik mesin, teknik kimia, fisika, dan ekologi. ${ }^{43}$

Hukum termodinamika I biasa disebut dengan hukum kekekalan energi. Prinsip hukum termodinamika I, sebagaimana dikatakan oleh Eugene P. Odum, ${ }^{44}$ adalah bahwa energi dapat berubah dari satu bentuk ke bentuk lain, namun energi tidak dapat diciptakan dan tidak dapat dimusnahkan. Pandangan ini semakna dengan teologi kaum Mu'tazilah mengenai keberadaan alam. ${ }^{45}$

Teologi Mu'tazilah meyakini bahwa unsur-unsur alam tidak musnah, melainkan hanya mengalami perubahan bentuk. Istilah teknis yang digunakan oleh M u'tazilah untuk penyebutan perubahan unsur alam dari satu bentuk kepada bentuk lain disebut inhilâl. Teori inhilâl ini dikembangkan oleh Al-Nizham yang asumsi dasarnya adalah bahwa dalam suatu benda terdapat unsur yang terus berubah dan masih bisa dibagi-bagi dan tidak berhenti. Istilah lain yang digunakan oleh Al-Nizham dalam menyebut teori unsur tanpa batas adalah tafrah, yang arti aslinya loncatan. ${ }^{46}$ Kajian lain yang berkembang di kalangan M u'tazilah adalah tentang entitas yang abadi dengan sendirinya (qadîm lidzatihi) dan entitas yang abadi karena dibuat abadi oleh yang lain (qadîm lighairihi). ${ }^{47}$ 
M enurut hukum termodinamika I dikatakan bahwa secara keseluruhan energi itu kekal, tidak dapat diciptakan dan tidak dapat pula dimusnahkan (konstan). Artinya, energi itu tidak dapat bertambah atau berkurang. ${ }^{48}$ Secara realitas, menurut hukum termodinamika I, memang energi itu hanya berubah dari satu bentuk kepada bentuk lain. Sebagai contoh energi air berubah menjadi energi nabati setelah diserap oleh tumbuh-tumbuhan, energi nabati berubah menjadi energi kalori dan dengan energi kalori manusia memiliki tenaga (energi) hingga mampu beraktivitas. Realitas ini menunjukkan bahwa energi itu tidak musnah dan tetap kekal. ${ }^{49}$

Berbeda dengan hukum Termodinamika II yang menyatakan bahwa energi mengalami penyusutan, sehingga akan mengalami kesirnaan. ${ }^{50}$ Berdasarkan hukum Termodinamika II, alam tidak memiliki karakter keabadian. Hukum ini sejalan dengan pandangan teologi aliran Al-As'yariyah, yang menyatakan bahwa substansi alam tidak memiliki karakter abadi. Sebagai benda tercipta (makhluk), alam ini adalah perkara baru (al-hadîth), akan mengalami kesirnaan, dan tidak memiliki karakter keabadian. Tidak terdapat esensi abadi yang terkandung di dalamnya, sebagaimana makhluk pada umumnya. Aliran Al-Asy'ariyah tidak memandang bahwa energi akan abadi, karena bertentangan dengan fitrah alami makhluk tercipta, sehingga berbatas jumlah dan volume.

\section{DEVELOPMENTALISM E: TEOLOGI EKSPLOITASI ENERGI}

Hukum termodinamika I (hukum kekekalan energi) merupakan landasan pemikiran masyarakat pembangunan (developmentalist society) dalam mengembangkan teologi energi berkelimpahan, ${ }^{51}$ yaitu sebuah pola pandang yang mengonsepkan eksploitasi energi tanpa batas. Masyarakat pembangunan berkeyakinan bahwa energi, di antaranya adalah air, adalah kekal, sehingga tidak akan habis, selain tidak terbatas jumlahnya.

Teologi energi berkelimpahan dapat pula disebut sebagai teologi energi antroposentris. Teologi energi antroposentris berkeyakinan bahwa sumber daya alam dan lingkungan yang tidak terbatas dan melimpah ruah itu harus dieksploitasi semaksimal mungkin untuk kemaslahatan dan kemanfaatan manusia. Sebagaimana dikatakan oleh para penganut aliran filsafat sosial fenomenologi52 bahwa sistem keyakinan suatu masyarakat berpengaruh terhadap perilakunya, maka teologi energi antroposentris menjadi landasan perilaku masyarakat yang boros energi. Mereka melakukan eksploitasi terhadap sumber daya alam tanpa batas dan menggunakannya 
secara tidak hemat. Selain itu, mereka berkeyakinan bahwa ukuran masyarakat maju adalah apabila tingkat konsumsi energinya tinggi dan masyarakat terbelakang adalah mereka yang tingkat konsumsi energinya rendah.

Lain halnya dengan prinsip hukum termodinamika II, yang menyebutkan bahwa proses transformasi energi tidak ada yang berlangsung secara utuh..$^{53}$ Artinya, perubahan energi dari satu bentuk ke bentuk lain pasti mengalami penyusutan dan menimbulkan limbah. Hukum termodinamika II biasa disebut dengan hukum entropi. Hukum entropi dikembangkan petama kali oleh Rodolf Clausius tahun 1868. ${ }^{54}$

Menurut hukum termodinamika II energi yang ada tidak seluruhnya dapat dipakai untuk melakukan aktivitas. Karena itu, penggunaan energi untuk kerja tidak mungkin mencapai efisiensi $100 \%$. Sebagai contoh, kalau kita menggunakan bensin sebanyak 1.000 satuan energi untuk memutar mesin, hasil kerja mesin itu selalu kurang dari 1.000 satuan energi. ${ }^{55}$

Hukum termodinamika II mengungkap perihal hukum alam yang bersifat universal, yaitu naiknya entropi dalam transformasi energi pada penggunaan sumber daya alam. Entropi adalah bagian energi total yang tidak dapat digunakan untuk melakukan kerja. ${ }^{56}$ Pada proses penggunaan energi yang bersifat tidak terbalikkan, entropi alam raya bertambah. Dalam rantai makanan, materi dan energi mengalir dari makhluk yang dimakan ke makhluk yang memakan. Tetapi, berbeda dengan materi yang mempunyai aliran berupa daur, arus energi bersifat satu arah. ${ }^{57}$

Menurut Jeremi Rifkin, sebagaimana disebutkan oleh Mujiyono Abdillah, dari hukum termodinamika I- hukum kekekalan energi-dan termodinamika II-hukum penyusutan energi-dapat dibuat sebuah pernyataan ekologis, yaitu: masyarakat ekologi percaya bahwa secara keseluruhan energi di dunia ini adalah kekal dan secara keseluruhan entropi selalu meningkat. ${ }^{58}$

A pabila menggunakan teori Mu'tazilah yang menyatakan bahwa alam ini bermula dari ketiadaan dan abadi (qadim), serta digabungkan dengan teori termodinamika I, maka air adalah akan tetap lestari. ${ }^{59}$ Hukum kelestarian energi air didasarkan pada kenyataan bahwa energi air itu tidak dapat dimusnahkan. Siklus hidrologi membuktikan fakta ini. Ketika air diserap oleh tumbuhan, ia akan kembali menjadi uap melalui sinar matahari (transpirasi), begitu juga air yang dikonsumsi oleh manusia akan mengalami penguapan yang pada akhirnya akan kembali menjadi air. M anusia hanya 
mengubahnya dari satu bentuk kepada bentuk lain.

Kemudian, bila ditimbang dengan teori termodinamika II atau hukum entropi, proses terjadinya transformasi energi air dari satu bentuk ke bentuk lain dipastikan menimbulkan limbah, termasuk menimbulkan pencemaran lingkungan karena sudah merupakan hukum alam (sunatullah). Hukum alam ini membentuk sebuah sistem keyakinan deterministis di kalangan masyarakat pengguna energi bahwa limbah dan pencemaran tidak bisa dihindari, apapun cara yang dilakukan oleh manusia untuk menghindarinya. Pencemaran lingkungan yang ditimbulkan oleh proses transformasi tersebut selalu meningkat, sejalan dengan peningkatan jumlah penduduk. Penambahan jumlah penduduk selalu ekuivalen dengan peningkatan konsumsi energi air, juga dengan jumlah limbah yang dihasilkan. Para penganut keyakinan deterministis, salah satu di antara mereka adalah L. Ortolanto, meyakini bahwa lingkungan telah ditakdirkan secara pasti untuk menampung limbah. Ortolanto menyebutkan bahwa fungsi lingkungan adalah (1) sebagai ruang kehidupan, (2) pendukung kehidupan, (3) penyedia sumber daya alam, dan (4) sebagai penerima limbah. ${ }^{60}$

Kalangan deterministis mengonsepsikan bahwa lingkungan memiliki kewajiban menerima limbah secara alamiah. Lingkungan sebagai penerima limbah dan pengolahnya, menurut mereka, merupakan bentuk dari tugas utamanya. Oleh sebab itu, produksi limbah yang dilakukan oleh manusia tidak bertentangan dengan hukum dan fungsi alam. Manusia memiliki landasan alamiah untuk memproduksi limbah. Keyakinan ini menjadi teologi energi masyarakat teknologi modern yang cenderung berpandangan eksploitatif terhadap sumber daya alam dan menjadi landasan operasional mereka dalam mengeksploitasi sumber daya alam. Mereka mengembangkan keyakinan ini dari hukum termodinamika II, yang menegaskan bahwa secara alami entropi selalu muncul dari proses transformasi energi dari satu bentuk kepada bentuk lain, ditambah sebuah keyakinan bahwa menerima limbah adalah kewajiban alami lingkungan. ${ }^{61}$

Kebanyakan teolog Asy'ariyyahmemandang bahwa energi itu terbatas, seiring dengan karakter alam yang diciptakan (makhluk). Energi, secara khusus dan alam secara umum, memiliki batas waktu, baik adanya maupun masa habisnya. Para teolog Asy'ariyyah meyakini bahwa alam ini tidak abadi; memiliki batas awal dan akhir serta akan sirna. M ereka mendasarkan pandangannya pada salah satu pernyataan Allah dalam Al-Quran,Tidaklah kami ciptakan langit dan bumi, serta apa yang ada antara keduanya, 
melainkan dengan (tujuan) yang benar dan sampai waktu yang ditentukan, (QS Al-Ahqaf [46]: 3) dan Semua yang ada di bumi itu akan sirna, (QSAIRahman [55]: 26).

Teologi Asy'ariyyah menegaskan bahwa meyakini alam sebagai sesuatu yang terbatas adalah bagian dari pangkal keyakinan. Seorang Muslim tidak beriman sempurna kecuali memegang keyakinan bahwa alam ini (termasuk energi di dalamnya) adalah terbatas waktu (muajjal). Keyakinan bahwa alam ini akan abadi dan tidak memiliki masa awal (qadim) menimbulkan kerancuan teologi, yang dikenal dengan istilah Multi Eksistensi Abadi (ta'addud al-qudama). Keyakinan Multi Eksistensi Abadi adalah bentuk kemusyrikan. ${ }^{62}$

Belakangan di kalangan para ekolog berkembang pandangan mengenai keterbatasan energi oleh waktu. ${ }^{63}$ Para ekolog tersebut meyakini bahwa energi itu memiliki masa akhir. Keyakinan ini muncul setelah manusia mampu menjelajahi ruang angkasa. Sejak saat itu diketahui bahwa bumi ini merupakan planet kecil yang terbatas ukurannya. Keyakinan bahwa energi itu terbatas didasarkan pada fakta bahwa luas, volume, dan massa bumi adalah terbatas, tempat energi itu berada. ${ }^{64}$ Penulis memandang bahwa apabila ditakar berdasarkan realita dan fakta kosmik, pada dasarnya alam memiliki kemampuan recovery otomatis untuk menjaga kelestariannya. Substansi alam terus mengalami peremajaan dan berusaha memertahankan dirinya sendiri. Realita ini memerkuat pandangan teologi M u'tazilah yang menyatakan bahwa substansi alam tidak mengalami kepunahan, melainkan terus berubah dan bertahan pada susunan atomiknya. Substansi air tidak mengalami kesirnaan, melainkan hanya berubah bentuk. Materi di alam ini tidak mengalami kesirnaan, melainkan berubah dan berpindah tempat, sehingga sangat memungkinkan untuk dikembalikan, seperti suara yang bisa direkam atau cahaya yang bisa pantulkan ulang. Bahkan, substansi ruh manusia memiliki keabadian, karena ia akan masuk pada keabadian di akhirat, padahal dia pernah berada di arena materi, yaitu tubuh manusia.

\section{PENUTUP}

Berdasarkan uraian di atas dapat disimpulkan bahwa terdapat keterhubungan konsep dan premis antara konsep teologi dalam Islam, terutama terwakili oleh dua aliran kalam, yaitu Mu'tazilah dan AlAsy'ariyyah, dengan teori Termodinamika. Aliran Mu'tazilah memiliki 
kesamaan konsep dan prinsip dengan hukum Termodinamika I, yang memandang bahwa energi memiliki karakter kekal, sehingga tidak akan habis. Sedangkan, aliran Al-As'yariyah sehaluan dan satu prinsip dengan hukum Termodinamika II, yang menyatakan bahwa energi mengalami penyusutan, seiring dengan karakter alam yang terbatas ruang dan waktu.

Telaah teologi energi ini dapat dijadikan sebagai dasar pertimbangan dalam melakukan eksploitasi lingkungan. Berdasarkan teori Mu'tazilah, eksploitasi lingkungan dapat dilakukan tanpa batas, karena sifat alam yang tidak berbatas. Adapun didasarkan pada pandangan aliran Al-Asy'ariyah eksploitasi harus memertimbangkan sisi keterbatasannya.

Pandangan teologi alam yang berkembang di kalangan M u'tazilah tidak relevan dengan pandangan keumuman para ahli energi moderen yang menyatakan bahwa energi akan habis pada waktu tertentu. Adapun teologi alam yang dikembangkan para penganut Asya'ariyah memiliki persambungan dengan pandangan keumuman para ahli energi modern yang menyatakan bahwa energi di alam ini akan habis dan terbatas jumlah. Walaupun begitu, kelemahan pandangan penganut Asy'ariyah adalah terdapat dalam hal meniadakan substansi abadi yang menjadi materi ukhrawi, sehingga teologi Asy'ariyah tentang alam dapat menegasikan (menafikan) kehidupan akhirat. Adapun pandangan keabadian energi yang dikembangkan oleh para penganut $\mathrm{M}$ u'tazilah memiliki kelebihan dalam hal memerkuat adanya alam akhirat sebagai wadah substansi abadi.

\section{CATATAN AKHIR}

1 Forrest Clingerman dan Kevin O 'Brien, "Playing G od: W hy Religion Belongs in the Climate Engineering D ebate," Bulletin Of The A tomic Scientists [serial online], 70 (M ei 2014), hlm. 27.

2 Ibid.

3 JB. Banawiratma dan J. Muller, Berteologi Sosial Lintas IImu,(Jogyakarta: Kanisius, 1993), 214.

4 M ujiyono Abdillah, A gama Ramah Lingkungan Perspektif A I-Q uran, (Jakarta: Paramadina, 2001), hlm. 23-24.

5 A religious nature: Philosopher Seyyed Hossein Nasr on Islam and the environment. Bulletin $0 \mathrm{f}$ The A tomic Scientists [serial online] 15 (September 2015), hlm. 13-18.

6 Ali M ohamed AI-Damkhi, "Environmental Ethicsin Islam: Principles, Violations, and Future Perspectives," International Journal of Environmental Studies [serial online], 65 (Februari 2008), hlm. 11-31.

7 A bdillah,A gama Ramah Lingkungan Perspektif A I-Q uran, hlm. 24. 
8 Q adîm: berwujud tanpa waktu.

$9 \quad H$ âdits: berwujud di waktu tertentu

10 Terry M aksymowych, "Just Water: Theology, Ethics, and the G lobal Water Crisis," C atholic Library W orld [serial online], 85 (September 2014), hlm. 38.

11 Dalam surah AI-A nbiya ayat 30 dikatakan bahwa Allah menjadikan segala yang hidup dari air.

12 A bdul Aziz M ahmud A I-M ishri, Q anun A I-M iyah fi A I-tslam, (Suriah: D ar AIfikr, 2011), hlm. 55.

13 Ibid.

14 Ibid., hlm. 69-70.

15 Ibid., hlm.70.

16 Ija Suntana, Politik E konomi I slam (Siyasah M aliyah), (Bandung: Pustaka Setia, 2010), 94.

17 Juli Soemirat Slamet, K esehatan Lingkungan,(Jogyakarta: Gadjah M ada U niversity Press, 2004), hlm. 83.

18 ibid.

19 Q.S. Al-Anbiya:30.

20 Ibid.,hlm.84.

21 Nama lengkap Al-M ishri adalah Abd Al-Aziz Mahmud Al-Mishri. Karya penting beliau dalam bidang pengairan Islam adalah kitab yang berjudul, Q anun AI-M iyah fi Al-slam (H ukum Air dalam Islam). Kitab ini mengupas secara mendalam tentang hukum pengairan Islam yang dikomparasikan dengan hukum pengairan internasional.

22 Al-M ishri, $Q$ anun Al-M iyah fi Al-slam, hlm. 55-56.

23 Ija Suntana, Politik Ekonomi Islam (Siyasah M aliyah), hlm. 95.

$24 \mathrm{Ibid}, \mathrm{hlm} .96$.

25 Ibid.

26 Ibid., hlm.97

27 Ibid.

28 Muhammad ibn Yusuf Al-Andalusi A I-G haranathi, Tafsir A I-Bahr A I-M uhith, (Lebanon: Dar Al-Fikr, 1978), juz 1, hIm. 98.

29 Shaleh Mahmud Wahbi, Al-Bi'ah min M anzhurin Islamiyyin, (Damaskus: Dar Al-Fikr, 2010), hlm. 25.

30 Ibid.

31 Ibid.

32 Ibid., hlm. 27.

33 Slamet, K esehatan Lingkungan, hlm. 80.

34 A bdulfatah Al-H usaini, A I-M a' wa Al-tshah fi A I-tslam, (W H O : PerwakilanT imur Tengah, 2009), hIm. 2.

35 Teori tentang siklushidrologi air tidak menyentuh tentangasal mula air. Siklus ini hanya menjelaskan tentang proses alami air dalam menyediakan dan melestarikan dirinya, setelah air itu tersedia di muka bumi. Teori siklus hidrologis bukan penjelasan dari mana asal air datang. Bahkan, ketika muncul pertanyaan, dari mana air yang membentuk lautan di Bumi itu berasal, tidak 
terdapat penjelasan yang diterima secara umum oleh semua ilmuwan air.

Bioer

51 A bdillah, A gama Ramah Lingkungan Perspektif A I-Q uran, hIm. 55.

52 Filsafat fenomenologi dikembangkan oleg Alfred Schutz (1899-1959) dari pemikiran M ax W eber dalam buku TheE thic of Protestan. Aliran filsafat sosial ini memusatkan perhatiannya pada kesadaran dan perilaku masyarakat. Pengembangan secara lebih lanjut aliran ini dilakukan pada 1932 di Jerman oleh Schut ketika dia menulis sebuah buku yang berjudul The Phenomenology of Social World. Schuzt memusatkan pada cara orang memahami kesadaran orang lain sementara mereka hidup dalam aliran kesadaran mereka sendiri. Schutzjuga menggunakan perspektif intersubjektivitas dal am pengertian lebih luas untuk memahami kehidupan sosial, terutama mengenai ciri sosial pengetahuan. Banyak pemikiran Schutz yang dipusatkan terhadap aspek dunia sosial yang kehidupan-dunia (lifeworld) atau dunia kehidupan sehari-hari. Inilah yang dimaksud dunia intersubjektif. Dalam dunia intersubjektif orang menciptakan realitas sosial dan dipaksa oleh kehidupan sosial yang telah ada dan oleh struktur kultural ciptaan leluhur mereka. Di dalam dunia kehidupan itu banyak aspek kolektifnya, tetapi juga ada aspek pribadinya. Schutz 
membedakan dunia kehidupan antara hubungan tatap muka yang akrab (relasi-kami) dan hubungan impersonal dan renggang (relasi-mereka). Sementara hubungan tatap muka yang intim sangat penting dalam kehidupan, adalah jauh lebih mudah bagi sosiolog untuk meneliti hubungan impersonal secara ilmiah. M eski Schutz beralih perhatianya dari kesadaran ke dunia kehidupan intersubjektif, namun ia masi m men gemukakan hasil pemikirannya tentang kesadaran, terutama pemikirannya tentang makna dan motif tin dakan individual. Secara keseluruhan Schutzmemusatkan perhatian pada hubungan dialektika antara cara in dividu membangun realitas sosial dan realitas kultural (termasuk sistem keyakinan) yang mereka warisi dari para pendahulunya (Lihat: G oerge Ritzer-D ouglas). Goodman, Teori Sosiologi M odern, (Jakarta: Kencana, 2004), hlm. 94-95.

53 O dum, Basic Ecology, hlm. 86.

54 A bdillah, A gama Ramah Lingkungan Perspektif A I-Q uran, hIm. 57.

55 Soemarwoto, Ekologi, Lingkungan H idup, dan Pembangunan, hIm. 41.

$56 \mathrm{Ibid}, \mathrm{hlm} .376$.

57 Ibid., hlm. 41.

58 A bdillah, A gama Ramah Lingkungan Perspektif A I-Q uran, hlm. 57-58.

59 Ija Suntana, Politik Ekonomi Islam (Siyasah M aliyah), hIm. 120.

60 L. O rtolanto, Environmental Planning and D ecicion M aking, (Toronto: John W ile and Sons, 2002), hlm. 431.

61 Ija Suntana, Politik E konomi Islam, hlm. 123.

62 A bu Hamid Al-G hazali, A kidah tanpa Bid'ah, terj. Ija Suntana, (Bandung: Pustaka H idayah, 2005), hlm. 103-106

63 A bdillah, A gama Ramah Lingkungan Perspektif A I-Q uran, hlm. 60.

$64 \mathrm{Ibid} .$, hlm. 60-61.

\section{DAFTAR PUSTAKA}

A bdillah, M ujiyono. 2001. A gama Ramah Lingkungan Perspektif A I-Q uran. Jakarta:

Paramadina.

Al-Damkhi, Ali Mohamed. 2008. Environmental Ethics in Islam: Principles, V iolations, and Future Perspectives. International Journal 0 f Environmental Studies. Serial O nline. N 0.65 .

Al-H usaini, A bdulfatah. 1999. A I-M a' wa Al-shah fi A I-slam. W H O : Perwakilan Timur Tengah.

AI-G hazali, A bu Hamid Muhammad. 2005. Akidah Tanpa Bid'ah, (Terj. Ija Suntana). Bandung: Pustaka H idayah.

A I-G haranathi, M uhammad ibn Yusuf AI-Andalusi. 1978. Tafsir A I-Bahr A I-M uhith. Lebanon: Dar Al-Fikr.

Al-Mishri, A bdul Aziz M ahmud. 1999. Q anun A I-M iyah fi Altslam. Suriah: Dar Alfikr.

Al-Zaukah, M uhammad Khamis. 1996. Al-Bi'ah wa M ahawir Tadahhawuriha wa A tsariha 'ala Shihhah A I-Insan. I skandariyah: D ar Al-M a'rifah Alfami'aiyyah. Banawiratma, JB. dan Muller. J. 1993. Berteologi Sosial Lintas IImu. Jogyakarta: 
Kanisius.

Clingerman, Forrest dan O 'Brien, Kevin. 2014. Playing G od: W hy Religion Belongs in the $\mathrm{ClimateEngineering} \mathrm{D} \mathrm{ebate.} \mathrm{Bulletin} \mathrm{of} \mathrm{The} \mathrm{A} \mathrm{tomic} \mathrm{Scientists.} \mathrm{Se-}$ rial O nline. No. 70.

H usaini, S. Waqar A hmad..1998. A IFikr A I-slami fi Tathwir M ashadir A I-M iyah wa A I-T haqah. New D elhi: G enuine Publicatons dan M edia.

Maksymowych, Terry. 2014. Just W ater: Theology, Ethics, and the G lobal Water Crisis," Catholic Library World. Serial O nline. No. 85.

McKelvey, Bill. 2004. Toward a 0th Law of Thermodynamics: O rder-C reation C omplexity Dynamics from Physics and Biology to Bioeconomics. Journal of Bioeconomics. Serial O nline. No.6.

O dum, Eugene. P. 1983. Basic E cology. Jepang: Saonders Collec Publishing.

O rtolanto, L. 1983. Environmental Planning and D ecicion M aking. Toronto: John W ile and Sons.

Ritzer, G oerge dan G oodman, D ouglas J. 2004. Teori Sosiologi M odern. Jakarta: Kencana.

Sadali, H asan. (et.al). 1988. Ensiklopedi Indonesia. Jakarta: I khtiar Baru-Van H ove.

Slamet, Juli Soemirat. 2004. K esehatan Lingkungan. Jogyakarta: Gadjah Mada U niversity Press.

Soemarwoto, O tto. 2004. Ekologi, Lingkungan H idup, dan Pembangunan. Jakarta: Djambatan.

Suntana, Ija. 2010. Politik E konomi Islam (Siyasah M aliyah). Bandung: Pustaka Setia. Wahbi, Shaleh Mahmud. 2004. Al-Bi'ah min M anzhurin Islamiyyin. Damaskus: Dar Al-Fikr.

A Religious N ature: Philosopher Seyyed H ossein Nasr on Islam and theEnvironment. 2015. Bulletin Of The A tomic Scientists. Serial O nline. N o.15. 
